\title{
How the immunoassay transformed C-peptide from a duckling into a swan
}

\author{
J. Roth • I. Whitford • R. Dankner • A. L. Szulc
}

Received: 9 August 2011 / Accepted: 11 November 2011 /Published online: 13 January 2012

(C) Springer-Verlag 2012

\begin{abstract}
This edition of 'Then and now' re-examines Lise Heding's very highly cited paper 'Radioimmunological determination of human C-peptide in serum', which was published in Diabetologia in 1975. We show how this article and other related articles by Heding contributed to heightened respect for C-peptide (and transformation of Heding's research programme). Initially thought of as an inert discard, Cpeptide in blood is now recognised as an excellent surrogate measure of insulin secretion under a wide range of conditions. The assay is especially valuable for acute ascertainment of the insulin secretory capabilities of patients with type 1 diabetes or of transplanted beta cells. The assay is also being used to monitor endogenous beta cell loss or in vivo expansion of beta cell mass over the long term. We conclude with two promising future applications: (1) measurements of C-peptide in
\end{abstract}

J. Roth · I. Whitford · R. Dankner · A. L. Szulc Laboratory of Diabetes and Metabolic Disorders, Feinstein Institute for Medical Research,

North Shore-Long Island Jewish Health System,

Hofstra North Shore-LIJ School of Medicine,

Manhasset, NY, USA

J. Roth · A. L. Szulc

Albert Einstein College of Medicine, Yeshiva University,

Bronx, NY, USA

R. Dankner

Unit for Cardiovascular Epidemiology, The Gertner Institute,

Sheba Medical Center, Tel Hashomer, Israel

R. Dankner

Sackler Faculty of Medicine, School of Public Health, Department of Epidemiology and Preventive Medicine, Tel Aviv University, Ramat Aviv, Tel Aviv, Israel

J. Roth $(\triangle)$

149-37 Powells Cove Blvd,

Whitestone, NY 11357, USA

e-mail: jesserothmd@hotmail.com blood (along with insulin, glucose, and $\mathrm{HbA}_{1 \mathrm{c}}$ ) at annual intervals as a potential approach to earlier diagnosis of diabetes; and (2) among many recent advances in recognising properties of C-peptide (including status as a candidate hormone), most promising is C-peptide as a possible therapy for diabetic neuropathy and nephropathy.

Keywords C-peptide · C-peptide history · Diabetes . Diabetic nephropathy . Diabetic neuropathy . Early diagnosis of diabetes $\cdot$ Immunoassay $\cdot$ Insulin

\section{Introduction}

C-peptide was cursed from early infancy by its name. The naming of a newborn hormone, like characters in the Bible (e.g. Jacob, Moses), can relate to a dynamic event surrounding its birth (e.g. growth hormone, follicle-stimulating hormone). Alternatively, the biological source inspires the naming (e.g. insulin, thyroxine). That this endocrine peptide's name is only a single letter has been a negative, but $\mathrm{C}$ was an especially poor choice in the biomedical community. Members of that community have typically been very grade conscious from childhood. An 'A' (officially 'excellent') is considered good. ' $\mathrm{B}$ ' (officially, 'good') is a setback, while ' $\mathrm{C}$ ' (officially, 'passing') is considered by this community to be a failure. Common parlance reflects similar attitudes. Plan A is the best. When thwarted, turn to Plan B. Introducing Plan C suggests impending defeat.

\section{Intellectual ancestry of C-peptide}

Minkowski discovered the glucose-regulating internal secretion of the pancreas in 1889 [1]. In 1909 de Meyer named it 
insuline [2]. After many failures in Europe and North America, insulin was isolated and purified by Banting, Best, Collip and Macleod in Toronto in 1921 [3]. With help from Connaught and Lilly, they swiftly introduced insulin for the treatment of diabetes, which led to the Nobel Prize for Banting and Macleod [3].

In the 1950s Sanger's group elucidated the structure of insulin, including the sequence of amino acids in the A-chain and B-chain, the arrangements of the disulfide bonds and the species-based variations in amino acid sequence, achievements that led to the first of Sanger's two Nobel Prizes. In 1960, Yalow and Berson introduced the radioimmunoassay for insulin [4]. For the first time in the century-old history of endocrinology, the tiny amount of a peptide hormone present in blood could be measured with specificity and accuracy, revolutionising all of biology and medicine. Yalow was awarded the Nobel Prize in 1977 [5], 5 years after Berson's death.

\section{Discovery of proinsulin and C-peptide}

It was widely believed that, after being synthesised separately, the insulin A-chain and B-chain were joined to form the two-chain intact hormone. Steiner's brilliant pulse-chase experiments showed that the two-chain hormone came from a single-chain precursor dubbed 'proinsulin' [6-8]. (The name was coined by Carpenter a year before its discovery.) The peptide that linked the B-chain of insulin to the A-chain was called the connecting piece (see Fig. 1). Later, Steiner et al. showed that the complete conversion of proinsulin to insulin involved proteolytic cleavages at each end of the connecting piece to yield insulin, C-peptide and free amino acids [8] (Fig. 1).

It soon became clear that insulin secretion is accompanied by the release of other insulin-related moieties [8-10], including intact proinsulin, two proinsulin intermediates and Cpeptide (Fig. 1). In normal individuals, insulin constitutes at least $80 \%$ of the total insulin-related material in blood, but under pathological conditions the incompletely converted components become a larger fraction of the total, sometimes constituting well over half. Immunoassays with insulinrecognising antibodies and those with C-peptide-directed antibodies would each be measuring multiple different species.

\section{Lise Heding's research}

For a brief period, immunoassay measurements appeared to be simple: insulin was insulin, glucagon was glucagon. Quickly, multiple complexities were recognised; the hormone immunoassayed in blood was composed of more than one element. Lise Heding was particularly clever and successful in

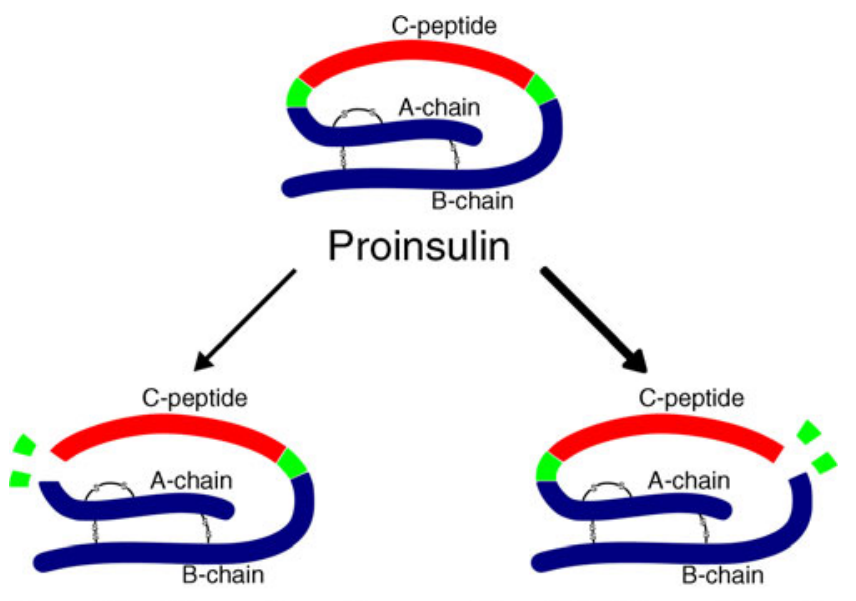

Des-64,65 proinsulin

Des-31,32 proinsulin

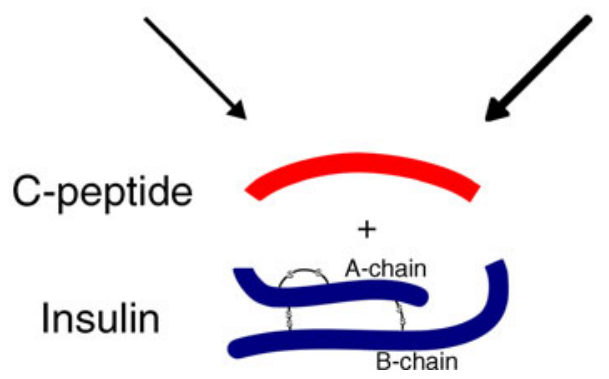

Fig. 1 Processing of proinsulin. Preproinsulin, the initial gene product, is converted into proinsulin in the Golgi apparatus at early stages of protein biosynthesis (not shown). In the beta cell most, but not all, proinsulin is converted into insulin in a multi-step process that requires prohormone proconvertase $1 / 3$, prohormone proconvertase 2 and carboxypeptidase $\mathrm{E}$. (As described in [7], in humans the pathway on the right is more efficient, as indicated by the heavier arrows.) The products of these enzymes include the two variants of intermediately processed protein, C-peptide, insulin and the four cleaved amino acids that linked C-peptide to insulin: three free arginine residues and one lysine residue. In blood, all five insulin-related species are present; C-peptide is the most abundant. Adapted from J Biol Chem [7] with permission, (C) 2011 The American Society for Biochemistry and Molecular Biology

creating modifications to immunoassays that would allow measurements of one entity in the presence of another, closely related moiety.

Patients treated with insulin develop anti-insulin antibodies. Insulin in blood partitions, in part, to the circulating antibodies. Lise Heding introduced a modified procedure that permitted measurement of both free and antibody-bound insulin in the same sample [11]. At about this time, many new hormones were being discovered. It often emerged that an individual hormone was part of a larger family of hormones that had partially overlapping structures and immunoactivities. Lise Heding showed how classic pancreatic glucagon and newly discovered gut glucagon could be distinguished in her assay [12]. (The gene for glucagon yields different peptides when expressed in pancreatic alpha cells compared with intestinal $\mathrm{L}$ cells.) The third very highly cited paper by Lise Heding, a major topic of 
our article, provides a method for measuring free C-peptide in serum in the presence of precursor molecules that contain the whole C-peptide sequence within their structures [13].

\section{Immunoassay of C-peptide}

Immunoassays for C-peptide by Lise Heding and by others yielded many surprising new insights. The major finding was that C-peptide was a better marker of insulin secretion than insulin itself, especially in blood samples from patients or lab animals. Both moieties are secreted at the same time in equimolar amounts. Insulin metabolism, especially on first pass through the liver, yields a widely varying rate of destruction of insulin but not of C-peptide. Likewise, insulin's disappearance from plasma and its degradation are significantly affected by insulin receptor concentrations [14, 15], which undergo substantial swift regulation throughout the body; C-peptide escapes these uncertainties. Overall, C-peptide is degraded more slowly and at a more regular rate, yielding a more predictable measure of insulin secretion than insulin itself.

\section{Practical applications}

The advent of immunoassays for $\mathrm{C}$-peptide and the finding that C-peptide is a superior marker for insulin secretion launched a torrent of new publications that went hand in hand with a widening use of the immunoassay [16]. One exciting finding from Heding's group with their new assay was the demonstration that at diagnosis about one-third of patients with type 1 diabetes have normal levels of C-peptide, providing evidence of residual islet function [17]. Heding's assay was then used to assess disease progression in patients with type 1 diabetes. They showed that, 3-5 years after onset, there was a distinct decline in the fraction of diabetic individuals who sustained normal C-peptide secretion, underscoring the assay's utility as an ongoing barometer of residual beta cell endocrine function.

Monitoring therapeutic efficacy The measurement of Cpeptide in blood is of ever-growing importance as a tool to assess the efficacy of the multiple therapies that are being introduced to (1) impede or halt the immune destruction of residual beta cells; and/or (2) stimulate growth of the mass of insulin-secreting beta cells. C-peptide levels in the basal state and following the administration of secretagogues are very useful guides. Xenografts of beta cellcontaining tissues are always under threat of immune destruction. Precise measurements of C-peptide (as a surrogate for insulin secretion) allow optimal titration of antirejection therapy.
Measuring insulin in the presence of antibodies Antibodies to insulin are present in insulin-treated patients (though this is less of a problem with currently used insulins) as well as in patients with auto-immunity. In antibody-bearing patients, plasma insulin levels are even more inaccurate as guides to insulin secretion than in antibody-free patients. Cpeptide measurements bypass this problem.

Fasting hypoglycaemia Patients with unexplained hypoglycaemia that is reproduced by fasting present a challenge to determine the aetiology and proper therapy. Measurements of C-peptide, along with insulin, can be very informative. High levels of insulin and C-peptide are found with insulinomas (or surreptitious use of sulfonylureas) as well as in individuals with hyperinsulinaemic hypoglycaemia syndromes. High insulin with low C-peptide is typical of surreptitious insulin administration. Low insulin and low C-peptide are found in patients with tumours producing IGF-2 [18].

Heding and her colleagues also used the C-peptide assay to measure insulin secretion in adults with acute pancreatitis, with cirrhosis, after glucagon in type 2 diabetes, during ethanol-induced hypoglycaemia, during exercise, in normal children during development, in hyperinsulinaemic children with an insulin receptor defect and in newborn infants of diabetic mothers.

\section{Prospects for the future}

John F Kennedy warned that 'Those who look only to the past or present are certain to miss the future.' We present here two themes for the future: (1) annual measurements of blood levels of fasting $\mathrm{C}$-peptide (along with insulin, glucose and $\mathrm{HbA}_{1 \mathrm{c}}$ ) are a new approach to detect the metabolic changes that antedate and warn of the clinical onset of type 2 diabetes; and (2) among the many newly discovered properties of $\mathrm{C}$ peptide, applications for diabetic neuropathy and nephropathy are the most promising.

C-peptide levels as a herald of diabetes With increasing recognition of the breadth and durability of the adverse effects of hyperglycaemia, even when mild, efforts are being directed towards the earlier diagnosis of diabetes. Introducing a personalised approach, we believe that serial measurements of glucose, $\mathrm{HbA}_{1 \mathrm{c}}$ insulin and C-peptide will serve as a herald of diabetes. Typically, diabetes (as well as impaired fasting glucose and impaired glucose tolerance) are diagnosed when an individual's blood glucose levels (fasting or post-glucose) exceed some upper limit of the normal range-where the normal range is based on the whole population. In a normal individual over time, the fasting blood glucose adheres to a much narrower range than that of the whole population. An individual's 
glucose will rise and break out of its own range several years before it reaches a level at which we diagnose diabetes (using population-based norms). We have labelled this condition 'dysglycaemia'. We propose that an individual's blood glucose (and $\mathrm{HbA}_{1 \mathrm{c}}$ ) should be measured at regular intervals and that a confirmed breakout from that individual's range should trigger an anti-diabetes therapeutic regimen, specifically, weight control and exercise [19].

There is evidence to suggest that insulin resistance, a centrepiece of the metabolic syndrome, has an even earlier onset [20]. Insulin resistance is marked by a rise in the basal insulin concentration (and in the basal level of C-peptide). With a similar logic, we propose measurements of insulin and C-peptide at regular (annual) intervals to promptly detect the breakout of these variables from the individual's own normal range, a condition we label as 'dysinsulinaemia', which is also worthy of therapeutic intervention [19, 20]. (As a corollary, insulin and C-peptide measurements, basal and stimulated, performed at regular intervals may be widely useful in the early recognition of the deterioration that leads to type 1 as well as type 2 diabetes.)

Our zeal to institute such early diagnostic strategies is based on increasing evidence that diabetes produces widespread abnormalities at an early stage, many of which are not fully reversible. The efficacy and safety of first-line therapy, i.e. improvements in physical exercise and diet (composition and total calories), offer further encouragement.

C-peptide therapies It was initially believed that the biological role of C-peptide ended when intact insulin was formed, analogous to residua of other peptide precursors known at that time, such as those of proteolytic enzymes and neurophysin. This belief was strengthened by the finding that C-peptides of widely different lengths and amino acid sequences, occurring naturally or synthesised in the lab, were all efficient in producing intact insulin. Appreciation of the growing evidence that $\mathrm{C}$-peptide had biological effects in vitro and in vivo, in animals and humans, has been dampened by the failure of investigators to define a specific receptor that mediates these actions.

Despite this missing piece, the evidence for the bioactivity of C-peptide is compelling, including mounting evidence that C-peptide may be a hormone [21]. In patients with type 1 diabetes (and in animal models), diabetic neuropathy is improved by C-peptide administration. C-peptide also provides a benefit for patients (and animal models) with diabetic nephropathy [22-24]. Particularly impressive is the finding that the peptide dampens the early glomerular hyperfiltration and enlargement that are typical preludes to diabetic nephropathy [24]. These promising therapeutic findings are bolstered by a series of other C-peptide studies, including interactions with insulin oligomers, binding specifically to the membranes of many cell types and activation of multiple pathways including activation of $\mathrm{Na}^{+} / \mathrm{K}^{+}$-ATPase, of eNOS, and several transcription factors, as well as insulin signals downstream of the insulin receptor [25].

\section{Conclusion}

The shift of Lise Heding's research agenda into immunoassays was transformative, for C-peptide and for her as a researcher. Her many papers in this area-including the three highly cited papers mentioned above-moved her to centre stage of research in diabetes, metabolism and gastrointestinal endocrinology, leading to her selection as Claude Bernard Lecturer of the European Association for the Study of Diabetes, the highest honour of the Association [26].

The ugly duckling, 'an unpromising child who develops into a person of unusual beauty, intelligence or the like - from a fable by Hans [Christian] Andersen of a swan hatched by a duck' is used here as a metaphor referring to the emergence of C-peptide [27]. The metaphor also applies to the remarkable transformation of Lise Heding's scientific programme.

Acknowledgements We are indebted to JR Zierath (Karolinska Institutet, Stockholm, Sweden) for inviting us to participate in the launch of the 'Then and now' series; to DF Steiner (University of Chicago, Chicago, IL, USA) for many facts and insights related to multiple aspects of the paper (including reminding us that the original name for C-peptide was proinsulin C-peptide); to MJ Brownstein (formerly from NIMH/NIH, Bethesda, MD, USA) for the analogy of C-peptide and insulin to copeptin and vasopressin; to J Ludvigsson (Linköping University, Linköping, Sweden) for insights about Lise Heding; and to S Qureshi (North Shore-LIJ, Manhasset, NY, USA) for expert editorial assistance. We would also like to thank S Englard (Albert Einstein College of Medicine, Yeshiva University, Bronx, NY, USA), N Fleischer (Albert Einstein College of Medicine), H Jornvall (Karolinska Institutet), RJ Mahler (Weill Cornell Medical College, New York, NY, USA), AA Sima (Wayne State University, Detroit, MI, USA), AJ Szabo (Lenox Hill, New York, NY, USA) and J Wahren (Karolinska Institutet). The ideas presented in the section on the proposed future use of personalised glucose (and $\mathrm{HbA}_{1 \mathrm{c}}$ ) and personalised insulin (and $\mathrm{C}$-peptide) in the early diagnosis of diabetes represent emerging concepts based on many stimulating discussions by $\mathrm{J}$ Roth and $\mathrm{R}$ Dankner with teammates M Bergman (New York University, New York, NY, USA), A Chetrit (Gertner Institute for Epidemiology and Health Policy Research, Chaim Sheba Medical Centre, Tel Hashomer, Israel) A Danoff (New York University), BC Hansen (University of South Florida, Tampa, FL, USA), N Kohn (North Shore-LIJ) and ML Lesser (North Shore-LIJ). J Roth's academic programme receives support from the Feinstein Institute for Medical Research, Manhasset, NY; the Russell Berrie Foundation, Teaneck, NJ; and the Alan and Tatyana Forman family.

J Roth dedicates this article to the memory of Gustav Schonfeld, MD, scholar, friend and colleague for over 50 years. Dr Roth recalls with gratitude the hospitality provided by Dr Schonfeld, his family and his classmates during Dr Roth's sojourn in St Louis.

Contribution statement All authors contributed to the conceptualisation and writing of the paper and all authors approved the version to be published. 
Duality of interest The authors declare that there is no duality of interest associated with this manuscript.

\section{References}

1. von Mering J, Minkowski O (1889) Diabetes Mellitus nach Pankreasextirpation. Arch Exp Path u Pharmakol 26:371-387 (article in German)

2. De Meyer J (1909) Action de la sécrétion interne du pancréas sur différents organes et en particulier sur la sécrétion rénale. Arch Fisiol 7:96-99 (article in French)

3. Bliss M (1982) The discovery of insulin. McClelland and Stewart Limited, Toronto

4. Yalow RS, Berson SA (1960) Immunoassay of endogenous plasma insulin in man. J Clin Invest 39:1157-1175

5. Roth J (2011) A tribute to Rosalyn S. Yalow. J Clin Invest 121:29492951

6. Steiner DF, Oyer PE (1967) The biosynthesis of insulin and a probable precursor of insulin by a human islet cell adenoma. Proc Natl Acad Sci U S A 57:473-480

7. Steiner DF (2011) Adventures with insulin in the islets of Langerhans. J Biol Chem 286:17399-17421

8. Steiner DF (2004) The proinsulin C-peptide - a multirole model. Exp Diabesity Res 5:7-14

9. Roth J, Gorden P, Pastan I (1968) "Big insulin": a new component of plasma insulin detected by immunoassay. Proc Natl Acad Sci U S A 61:138-145

10. Rubenstein AH, Cho S, Steiner DF (1968) Evidence for proinsulin in human urine and serum. Lancet 1:1353-1355

11. Heding LG (1972) Determination of total serum insulin (IRI) in insulin-treated diabetic patients. Diabetologia 8:260-266

12. Heding LG (1971) Radioimmunological determination of pancreatic and gut glucagon in plasma. Diabetologia 7:10-19

13. Heding LG (1975) Radioimmunological determination of human C-peptide in serum. Diabetologia 11:541-548
14. Terris S, Steiner DF (1976) Retention and degradation of ${ }^{125}$ I-insulin by perfused livers from diabetic rats. J Clin Invest 57:885-896

15. Zeleznik AJ, Roth J (1978) Demonstration of the insulin receptor in vivo in rabbits and its possible role as a reservoir for the plasma hormone. J Clin Invest 61:1363-1374

16. Brandenburg D (2008) History and diagnostic significance of Cpeptide. Exp Diabetes Res 2008:576862

17. Ludvigsson J, Heding LG (1976) C-peptide in children with juvenile diabetes. A preliminary report. Diabetologia 12:627630

18. Koch CA, Rother KI, Roth J (1999) Tumor hypoglycemia linked to IGF-II. In: Rosenfeld RG, Roberts CT (eds) The IGF system: molecular biology, physiology, and clinical applications. Humana Press, Totowa, pp 675-698

19. Dankner R, Danoff A, Roth J (2010) Can 'personalized diagnostics' promote earlier intervention for dysglycaemia? Hypothesis ready for testing. Diabetes Metab Res Rev 26:7-9

20. Dankner R, Chetrit A, Shanik MH, Raz I, Roth J (2009) Basal-state hyperinsulinemia in healthy normoglycemic adults is predictive of type 2 diabetes over a 24-year follow-up: a preliminary report. Diabetes Care 32:1464-1466

21. Wahren J, Ekberg K, Jornvall H (2007) C-peptide is a bioactive peptide. Diabetologia 50:503-509

22. Sima AA, Zhang W, Sugimoto K et al (2001) C-peptide prevents and improves chronic type I diabetic polyneuropathy in the BB/ Wor rat. Diabetologia 44:889-897

23. Samnegard B, Jacobson SH, Jaremko G et al (2005) C-peptide prevents glomerular hypertrophy and mesangial matrix expansion in diabetic rats. Nephrol Dial Transplant 20:532-538

24. Luppi P, Cifarelli V, Wahren J (2011) C-peptide and long-term complications of diabetes. Pediatr Diabetes 12:276-292

25. Sima AAF (ed) (2011) Diabetes and C-peptide. Scientific and clinical aspects. Humana Press, New York

26. Ludvigsson J (2009) Lise G. Heding, 1936-2008. Diabetologia $52: 2245-2246$

27. 'Ugly duckling' (1953) In: Webster's New Collegiate Dictionary. GC Merriam Co., Springfield 